\title{
Effect of Diquat on Cell Growth and Macromolecule Synthesis in Cultured Pneumocytes
}

\author{
Kotaro Saito \\ Division of Neonatology, Department of Pediatrics, the \\ University of Texas Health Science Center at Dallas, 5323 \\ Harry Hines Boulevard, Dallas, Texas 75235, USA
}

\begin{abstract}
SaIto, K. Effects of Diquat on Cell Growth and Macromolecule Synthesis in Cultured Pneumocytes. Tohoku J. exp. Med., 1986, 148 (1), 35-39— The effects of diquat (DQ) on cell growth and macromolecule synthesis were investigated in cultured rat, feline and human. pneumocytes. DQ at $10^{-3} \mathrm{M}$ and $10^{-5} \mathrm{M}$ showed time- and dose-dependent inhibition of cell growth for 7 days. The incorporation of ${ }^{3} \mathrm{H}$-thymidine, ${ }^{3} \mathrm{H}$-uridine and ${ }^{14} \mathrm{C}$-leucine into DNA, RNA and protein was reduced to $0-47 \%$ by $10^{-3} \mathrm{M}$ of $\mathrm{DQ}$, and that of ${ }^{14} \mathrm{C}$-leucine into protein of $\mathrm{A}-549$ cells was reduced to $67 \%$ by $10^{-5} \mathrm{M}$ of DQ. Among the cells examined, A-549 cells derived from human lung were the most resistant to the inhibitory effects of DQ on cell growth and macromolecule synthesis. On the other hand, human lung embryonic fibroblast cells and L-2 cells derived from rat lung were the most sensitive to the toxicity of DQ. These results indicate that the inhibitory effects of DQ on cell growth and on macromolecule synthesis are dependent on the concentrations of DQ administrated, and that species differences in the sensitivity to DQ toxicity may exist.— diquat; pneumocytes; DNA ; RNA ; protein
\end{abstract}

Diquat ( $\mathrm{N}, \mathrm{N}^{\prime}$-ethylene-2, 2' bipyridilium, DQ), which is a bipyridilium salt, has been shown to have herbicidal property. Its herbicidal activity appears to depend, in part, on the ease of one electron reduction of $\mathrm{DQ}^{++}$to form superoxide anion $\left(\mathrm{O}_{2}^{-}\right)$from the stable, but air-sensitive radical cation of $\mathrm{DQ}^{+}$(Dodge 1971). It has been suggested that DQ injected intravenously into mice is distributed throughout most tissues, except for brain and spinal cord (Litchfield et al. 1973). Animals given DQ die without obvious histological changes that might account for death (Clark and Hurst 1970).

Recently, an accidental lethal poisoning by DQ ingestion was reported (Powell et al. 1983). DQ has been said to affect cyclic AMP, ACTH or glucose level of rat (Rose et al. 1974), but the biological effects underlying the mammalian toxicity of DQ are not fully understood. Once DQ has been suggested to be accumulated into cultured pneumocytes (Saito and Menzel 1979), and the cells used in the present study have been shown to be sensitive to the toxicity of paraquat (PQ), another bipyridilium herbicide related to DQ (Saito 1985). This

Received May 24, 1985; accepted for publication October, 1985. 
study of the biochemical effects occurring in cultured type II pneumocytes of three species after DQ administration has been undertaken in an attempt to understand the metabolic disturbances underlying the toxicity of DQ.

\section{Materials and Mthods}

Cell culture. Four kinds of cell lines, AK-D cells derived from feline embryonic lung (Kniazeff et al. 1976), L-2 cells derived from rat lung (Douglas and Kaighn 1974), A-549 cells derived from human lung (Lieber et al. 1976) and human embryonic lung fibroblast cells (HEL) (Peterson et al. 1978), were obtained from American Type Culture Collection (Rockville, MD, USA). AK-D cells and L-2 cells were cultured in $3 \mathrm{ml}$ of F-12K culture medium containing $15 \%$ and $20 \%$ fetal calf serum (FCS), respectively, A-549 cells and HEL cells were cultured in $3 \mathrm{ml}$ of Dulbecco's modified minimum essential medium with Earle's salts containing $10 \%$ FCS in $25 \mathrm{~cm}^{2}$ plastic tissue culture flasks at $37^{\circ} \mathrm{C}$. The tissue culture media were supplemented with $100 \mathrm{units} / \mathrm{ml}$ of penicillin $\mathrm{G}$ and $100 \mu \mathrm{g} / \mathrm{ml}$ of streptomycin.

Effect of $D Q$ on cell growth. AK-D cells, L-2 cells and A-549 cells were cultured with $10^{-5} \mathrm{M}$ and $10^{-3} \mathrm{M}$ of $\mathrm{DQ}$ or $\mathrm{PQ}$ for 7 days at $37^{\circ} \mathrm{C}$. The primary cell number was adjusted to $5 \times 10^{4}$ cells $/ \mathrm{ml}$. At each $24 \mathrm{hr}$, cells were trypsinized with $0.125 \%$ of trypsin and $0.02 \%$ of ethylenediamine teraacetic acid (EDTA) solution and cell numbers were counted in a hemocytometer. Tissue culture media were changed at each 2,4 and 6 days in culture. DQ and $\mathrm{PQ}$ were also added to the new culture media.

Effect of $D Q$ on macromolecule synthesis. Cells were incubated with $10^{-3} \mathrm{M}$ and $10^{-5}$ $\mathrm{M}$ of $\mathrm{DQ}$ at $37^{\circ} \mathrm{C}$ for $24 \mathrm{hr}$. At the begining of incubation, $0.05 \mu \mathrm{Ci} / \mathrm{ml}$ of ${ }^{3} \mathrm{H}$-thymidine (specific activity ; $2 \mathrm{Ci} / \mathrm{mmol},{ }^{3} \mathrm{H}-\mathrm{TdR}$ ), ${ }^{3} \mathrm{H}$-uridine (specific activity ; $2 \mathrm{Ci} / \mathrm{mmol},{ }^{3} \mathrm{H}-\mathrm{UdR}$ ) and ${ }^{14} \mathrm{C}$-leucine (specific activity ; $50 \mathrm{mCi} / \mathrm{mmol},{ }^{14} \mathrm{C}-\mathrm{LcR}$ ) were added to the media. The incubation was terminated by washing the cells with ice cold Dulbecco's phosphate buffered saline solution (PBS), $\mathrm{pH} 7.4$, for three times. The cells were treated with ice cold $10 \%$ trichloroacetic acid (TCA) for $10 \mathrm{~min}$ and then $5 \%$ TCA for $20 \mathrm{~min}$ twice and were dehydrated with addition of absolute ethanol at room temperature for $20 \mathrm{~min}$. The cells were dissolved by addition of $1 \mathrm{~N} \mathrm{NaOH}$. Aliquots were used to measure protein concentration by the method of Lowry (Lowry et al. 1951), other aliquots. were neutralized with $1 \mathrm{~N}$ $\mathrm{HCl}$ in order to count the radioactivity in POPOP liquid scintillation cocktail by a liquid scintillation technique. The cell protein concentration was standerdized by calf serm albumin. The cellular radioactivity was expressed to count per minute (cpm)/mg protein. The static analysis of the data was performed by Student's $t$ test. Tissue culture materials were obtained from GIBCO (Gland Island, NY, USA). The radioactive precursors were obtained from New England Nuclear (Boston, MA, USA). Other chemical reagents were obtained from Sigma Chem. Co. (St. Louis, MO, USA).

\section{RESULTS}

Cell growth. DQ produced a time- and dose-dependent inhibition of cell growth. DQ at $10^{-3} \mathrm{M}$ and $10^{-5} \mathrm{M}$ had significantly $\left(p<0.001\right.$ at $10^{-3} \mathrm{M}$ and $p<$ 0.01 at $10^{-5} \mathrm{M}$ ) stronger inhibitory effect on the cell growth, than did PQ at $10^{-3}$ $\mathrm{M}$ and $10^{-5} \mathrm{M}$. After $48 \mathrm{hr}$ in culture with $10^{-3} \mathrm{M}$ of $\mathrm{DQ}$, appreciable cell numbers in the flasks were not detected with AK- D cells (Fig. 1). In the other two cell lines, L-2 cells and A-549 cells, DQ at $10^{-3} \mathrm{M}$ and $10^{-5} \mathrm{M}$ had similar inhibitory effect on cell growth (Data not shown).

Macromolecule synthesis. The incorporation of radioacitive precursors of ${ }^{3} \mathrm{H}-\mathrm{TdR},{ }^{3} \mathrm{H}-\mathrm{UdR}$ and ${ }^{14} \mathrm{C}-\mathrm{LcR}$ into acid insoluble fractions of DNA, RNA and 


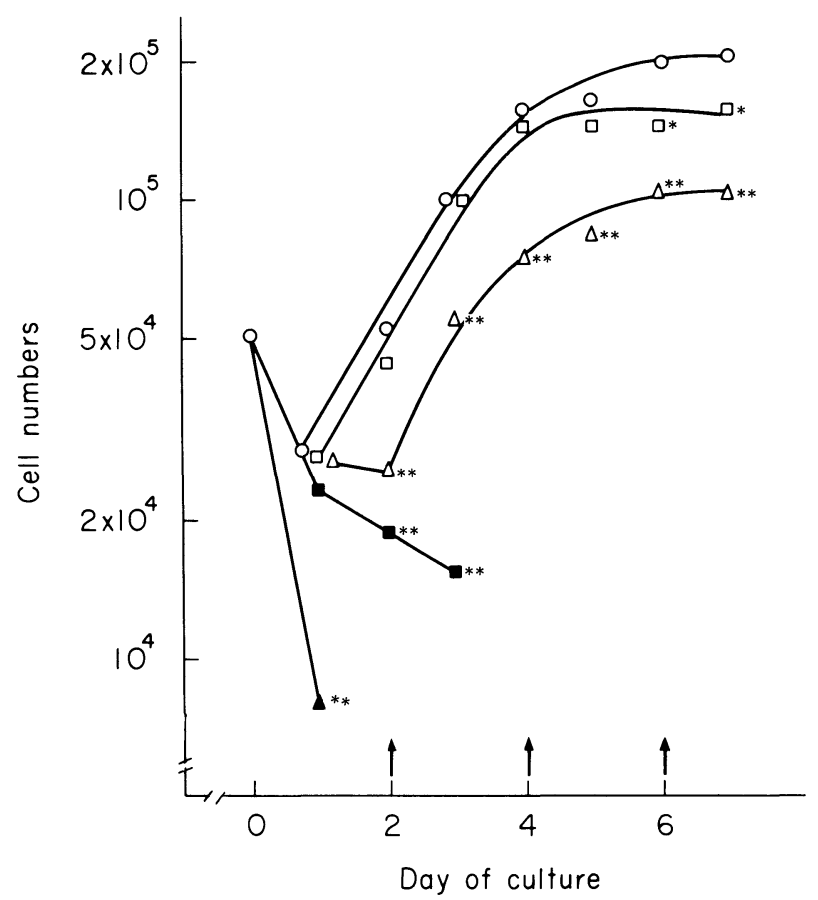

Fig. 1. Effect of DQ and $P Q$ on cell growth of AK-D cell.

Each point indicates mean numbers of cells $/ \mathrm{ml}$ of three samples.

Culture conditon is presented in the text. $\bigcirc-\bigcirc$, control ; $\triangle-\triangle, \mathrm{DQ}\left(10^{-5}\right.$

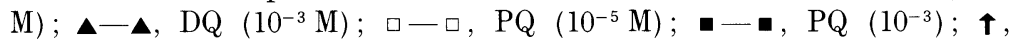
changing the culture mediun.

${ }^{*} p<0.05 ;{ }^{* *} p<0.01$.

protein, respectively, was significantly inhibited by $10^{-3} \mathrm{M}$ of DQ for $24 \mathrm{hr}$ in all of cells examined. The incorporation of ${ }^{3} \mathrm{H}-\mathrm{TdR}$ into DNA was reduced to $0 \%$ in L-2 cells and $24 \%$ in A-549 cells that of ${ }^{3} \mathrm{H}-\mathrm{UdR}$ into $\mathrm{RNA}$ was reduced to $0 \%$ in L-2 cells to $47 \%$ in A-549 cells and that of ${ }^{14} \mathrm{C}-\mathrm{LcR}$ into protein was also reduced to $0 \%$ in HEL cells and to $45 \%$ in A-549 cells by $10^{-3} \mathrm{M}$ of DQ for $24 \mathrm{hr}$ in culture. In the four cell lines examined, L-2 cells and HEL cells seemed to be most sensitive to DQ toxicity, and A-549 cells were most resistant to DQ toxicity. At a concentration of $10^{-5} \mathrm{M}$, DQ had no inhibitory effect on the incorporation of these precursors into macromolecules for $24 \mathrm{hr}$, except the reduction of ${ }^{14} \mathrm{C}-\mathrm{LcR}$ incorporation into protein of A-549 cells to $68 \%$ (Table 1 ). The total protein concentration of the cells in culture were reduced to $37 \%$ in AK-D cells, $65 \%$ in L-2 cells, $70 \%$ in HEL cells and $28 \%$ in A-549 cells. Thus a species difference in the ability of DQ to cause toxicity seemed to exist.

\section{Discussion}

In the present study, the biochemical effects of DQ on cultured pulmonary cell lines were examined to evaluate the toxicity of DQ. Because the same cell type could be derived from different species and the ease of propagation of cells 
TABLE 1. Effect of diquat on ${ }^{3} H-T d R,{ }^{3} H-U d R$ and ${ }^{14} C-L c R$ incorporation into the cells for $24 \mathrm{hr}$

\begin{tabular}{|c|c|c|c|c|}
\hline Cells & & ${ }^{3} \mathrm{H}-\mathrm{TdR}$ & ${ }^{3} \mathrm{H}-\mathrm{UdR}$ & ${ }^{14} \mathrm{C}-\mathrm{LcR}$ \\
\hline \multirow{3}{*}{$\begin{array}{c}\mathrm{L}-2 \\
(\mathrm{n}=4)\end{array}$} & Control & $297.4 \pm 17.4$ & $418.5 \pm 55.5$ & $279.5 \pm 66.4$ \\
\hline & $\mathrm{DQ} \quad\left(10^{-3} \mathrm{M}\right)$ & 0 & 0 & $8.8 \pm 1.7^{* *}$ \\
\hline & $\mathrm{DQ} \quad\left(10^{-5} \mathrm{M}\right)$ & $267.1 \pm 17.9$ & $456.3 \pm 37.7$ & $264.6 \pm 38.3$ \\
\hline \multirow{3}{*}{$\begin{array}{l}\text { AK-D } \\
(n=4)\end{array}$} & Control & $113.9 \pm 14.0$ & $101.1 \pm 3.2$ & $134.4 \pm 8.4$ \\
\hline & $\mathrm{DQ} \quad\left(10^{-3} \mathrm{M}\right)$ & $15.2 \pm 5.6^{* *}$ & $42.4 \pm 1.3^{* *}$ & $19.2 \pm 4.7^{* *}$ \\
\hline & DQ $\quad\left(10^{-5} \mathrm{M}\right)$ & $97.5 \pm 4.4$ & $102.1 \pm 4.8$ & $128.2 \pm 11.1$ \\
\hline \multirow{3}{*}{$\begin{array}{l}A-549 \\
(\mathrm{n}=4)\end{array}$} & Control & $743.6 \pm 63.6$ & $278.1 \pm 11.9$ & $209.7 \pm 8.6$ \\
\hline & $\mathrm{DQ} \quad\left(10^{-3} \mathrm{M}\right)$ & $177.9 \pm 14.9^{* *}$ & $132.4 \pm 35.7^{* *}$ & $94.6 \pm 6.4^{* *}$ \\
\hline & DQ $\quad\left(10^{-5} \mathrm{M}\right)$ & $690.8 \pm 58.9$ & $271.9 \pm 25.0$ & $142.5 \pm 16.8^{*}$ \\
\hline \multirow{3}{*}{$\begin{array}{l}\text { HEL } \\
(n=3)\end{array}$} & Control & $209.0 \pm 47.4$ & $160.6 \pm 1.8$ & $59.9 \pm 5.4$ \\
\hline & $\mathrm{DQ} \quad\left(10^{-3} \mathrm{M}\right)$ & $2.0 \pm 0.3^{* *}$ & $2.1 \pm 1.1^{* *}$ & 0 \\
\hline & $\mathrm{DQ} \quad\left(10^{-5} \mathrm{M}\right)$ & $197.7 \pm 38.2$ & $161.1 \pm 6.1$ & $54.1 \pm 5.4$ \\
\hline
\end{tabular}

Asterisks indirate significant $\left({ }^{*} p<0.05 ;{ }^{* *} p<0.01\right)$ difference of the control.

Values are means \pm S.D. of $\mathrm{cpm}\left(\times 10^{2}\right) / \mathrm{mg}$ protein.

Culture condition is presented in the text.

in culture, it was decided to use the four cell lines derived from three species. It has been reported that $\mathrm{PQ}$ has an inhibitory effect on macromolecule synthesis in these cell lines, i.e., the incorporation of ${ }^{3} \mathrm{H}-\mathrm{TdR}$ into DNA, that of ${ }^{3} \mathrm{H}-\mathrm{UdR}$ into RNA and that of ${ }^{14} \mathrm{C}$-LcR into protein were all eliminated to approx. $50 \%$ by $10^{-3} \mathrm{M}$ of PQ (Saito 1985). In this experiment, DQ had more marked inhibitory effect on cell growth and on macromolecule synthesis that PQ. The difference of the efficacy of these bipyridilium salts as inhibitors may be related to their redox potential, i.e., $\mathrm{E}_{0}$; $-348 \mathrm{mV}$ for $\mathrm{DQ}$ and $-446 \mathrm{mV}$ for $\mathrm{PQ}$.

It has been suggested that $\mathrm{DQ}$ at $10^{-3} \mathrm{M}$ does not alter the incorporation of ${ }^{14} \mathrm{C}-\mathrm{LcR}$ into protein of P 338Dl "Macrophage-like" cell line (Carmine et al. 1981). In the present study, DQ inhibited protein synthesis by $55 \%-100 \%$ in all kinds of cell lines examined, and by $32 \%$ at $10^{-5} \mathrm{M}$ in A-549 cells. The difference between $\mathrm{P} 338 \mathrm{D} 1$ cells and the four cells examined in response to DQ toxicity is not clear.

A-549 cells was shown to have a much higher ability to induce the level of superoxide dismutase by PQ than L-2 cells (Saito 1985). The more marked inhibitory effect of DQ at $10^{-3} \mathrm{M}$ on DNA, RNA and protein synthesis in L-2 cells and HEL cells than that in A-549 cells and AK-D cells may be due to the lower induction of superoxide dismutase in L-2 cells and HEL cells by DQ relative to A-549 cells and AK-D cells.

The biochemical mechanisms of the lethality of DQ is not clearly understood. It is presumed that DQ produces metabolic disturbances, such as an increase of glucose utelization in the liver of that of cyclic AMP in the adrenal gland of the 
rat (Rose et al. 1974) and depletion of NADPH in the lung of the rat (Witschi et al. 1977). In the present study, it was demonstrated that DQ has an inhibitory effect on cell growth. The inhibition of the cell growth might be related to the inhibition of incorporation of precursors into DNA, RNA and protein in the cells. The inhibition of uptake of these precursors into the cells by high concentration of DQ might be involved in the acute toxic mechanisms of DQ in humans and animals.

\section{Acknowledgments}

I would like to thank Dr. R.A. Prough, Professor of Department of Biochemistry, The University of Texas Health Sience Center at Dallas., Dallas, Texas, USA for his support in preparation of the manuscript.

\section{References}

1) Camine, E.L., Carchman, R.A. \& Borzelleca, J.H. (1981) Investigation into the mechanism of paraquat toxicity utilizing a cell culture system. Toxicol. appl. Pharmacol., 58, 353-362.

2) Clark, D.G. \& Hurst, E.W. (1970) The toxicity of diquat. Brit. J. industr. Med., 27, 51-55.

3) Dodge, A.D. (1971) The mode of action of bipyridilium herbicide, paraquat and diquat. Endeavour, 30, 130-141.

4) Douglas, W.H.J. \& Kaighn, M.E. (1974) Clonal isolation of differentiated rat lung cells. In Vitro, 10, 230.

5) Kniazeff, A.J., Stoner, G.D., Terry, L., Wagner, R.M. \& Hoppenstand, R.D. (1976) Characteristics of epitherial cells cultured from feline lung. Lab. Invest., 34, 495-455.

6) Lieber, M., Smith, B., Szakal, A., Nelson-Ree, W. \& Torado, G. (1976) A contineous tumor-cell line from a human lung carcinoma with properties of type II alveolar epitherial cells. Int. J. Cancer, 17, 62-70.

7) Lichfield, M.M., Daniel, J.W. \& Longshow, S. (1973) The tissue distribution of bipyridilium herbicide diquat and paraquat in rat and mice. Toxicology, 1, 155-165.

8) Lowry, O.H., Rosebrough, N,J., Far, A.L. \& Randall, R.J. (1951) Protein measurement with folin phenol reagent. $J$. biol. Chem., 193, 265-275.

9) Peterson, W.D., Stulberg, C.S., Swanborg, N.K. \& Robinson, A.R. (1978) Glucose-6phosphate dehydrogenase isoenzymes in human cell cultures: Determined by sucroseagar gel and cellulose acetate zymozans Proc. Soc. exp. Biol. Med., 128, 772-776.

10) Powell, D., Pond, S.M., Allen, T.B. \& Portale, A.A. (1983) Hemoperfusion in a child who ingested diquat and died from pontine infarction and hemorrhage. J. Toxicol. clin. Toxicol., 20, 405-420.

11) Rose, M.S., Crabtree, H.C., Fletcher, F. \& Wyatt, I. (1974) Biochemical effects of diquat and paraquat. Disturbance of the control of corticosteroid synthesis in rat adrenal and subsequent effects on the control of liver glycogen utilization. Biochem. $J .$, 138, 437-443.

12) Saito, K. (1985) Effect of paraquat on macromolecule synthesis in cultured pneumocytes. Tohoku J. exp. Med, 148, in press.

13) Saito, K. \& Menzel, D.B. (1979) Accumulation of paraquat and diquat by cultured type II cells. Toxicol. appl. Pharmacol., 48, A-58.

14) Witschi, H., Hirai, K. \& Cote, G. (1977) Primary events in lung following exposure to toxic chemicals. In: Biochemical Mechanisms of Paraquat Toxicity, edited by A. P. Autor, Academic Press, New York, pp. 1-16. 